\title{
REVIEW
}

\section{The immunopathogenesis of meningococcal disease}

\section{A J Kvalsvig, D J Unsworth}

J Clin Pathol 2003;56:417-422

This review describes the mechanisms of the immune response to meningococcal disease, examining the extent to which individual variation of the immune response can determine susceptibility. It concludes by summarising the difficulties encountered by recent efforts to develop new immunomodulatory treatments.

nvasive meningococcal disease is justly feared for its propensity to attack the young and healthy, with a rapid progression from mild symptoms to extreme morbidity and even death within the space of a few hours. It is notable that despite high public and professional awareness of the disease and prodigious advances in the management of severe sepsis, morbidity and mortality remain high. ${ }^{1-3}$

"Recent work has emphasised the profound effect of the patient's own immune response in determining the course and outcome of disease"

To make headway against this devastating disease, a fundamentally different approach is required. Recent work has emphasised the profound effect of the patient's own immune response in determining the course and outcome of disease. This suggests that in certain contexts, it can be useful to view meningococcal sepsis as an inflammatory disease, despite its infectious origin.

Accordingly, researchers investigating new treatment strategies for meningococcal disease are seeking to modify the immune response rather than develop ever bigger and better antimicrobial agents.

\section{BACKGROUND}

Meningococcal disease is caused by Neisseria meningitidis, a Gram negative encapsulated diplococcus, which is an obligate human pathogen.

Invasive meningococcal disease usually takes the form of meningitis or septicaemia, or a combination of the two. Although clear differentiation between these two states is not possible in the clinical setting, there is some evidence that patients presenting with meningitis alone have a milder disease course. ${ }^{4}$ In contrast, meningococcal septicaemia is associated with rapidly progressive shock and coagulopathy, which can be extremely difficult to manage. Although overall mortality from meningococcal disease is reported to be around $6-10 \%$ in the developed world, ${ }^{14-7}$ estimations of mortality for meningococcal septicaemic shock are much higher and vary between
$20 \%$ and $80 \%$, depending on the definition used..$^{8-13}$

\section{EPIDEMIOLOGY}

Invasive meningococcal disease is an important public health concern in both the developed and developing world. Because of its epidemic nature, there can be wide variations in incidence over time and between geographical regions. However, increased ease of travel in modern times has assisted the spread of epidemics between regions, as seen with the recent outbreak of meningococcal disease among Hajj pilgrims. ${ }^{14}$ Current figures for annual incidence in England and Wales are 5.2 cases/100 000. ${ }^{15}$

Classification by serogroup based on capsular polysaccharides is still the most common system for general purposes. In developed countries, up to $90 \%$ of infections are caused by serogroups B and C, whereas in Africa, serogroup A predominates. The excess cases resulting from infections in Hajj pilgrims were notable for being caused by serogroup W135. As shall be seen later, a finding of "unusual" serogroup disease can also be a marker of underlying immune problems.

\section{CARRIAGE TO INVASIVE DISEASE}

Mucosal immunity constitutes the first line of defence against meningococcal infection and is generally very effective, as shown by the fact that few carriers develop clinical disease. Although the prevalence of carriers as determined by throat swabs is usually in the order of $10 \%,{ }^{16}{ }^{17}$ more sensitive diagnostic techniques suggest that the rate of carriage may be somewhat higher. ${ }^{18}$ Although screening of populations has epidemiological interest, it is not yet possible to identify carrier individuals who are at risk of invasive disease.

The invasion of epithelial and endothelial cells is facilitated by colony opacity associated proteins and bacterial pili. ${ }^{19}$ Meningococci have evolved several mechanisms for evading the host immune response at the mucosal level, ${ }^{20-22}$ and many of these mechanisms continue to operate once the bacteria have accessed the circulation. ${ }^{23-25}$ It has recently been shown that the neisserial IgAl protease can induce a proinflammatory cytokine response in peripheral blood mononuclear cells. ${ }^{26}$ Interestingly, IgAl protease does not seem to induce the anti-inflammatory cytokine interleukin 10 (IL-10); this suggests one possible

Abbreviations: $\mathrm{BPI}$, bactericidal permeability inducing protein; CSF, cerebrospinal fluid; IL, interleukin; LPS, lipopolysaccharide; $\mathrm{MBL}$, mannose (or mannan) binding lectin; TLR, toll-like receptor; TNF, tumour necrosis factor 
mechanism for the excessive inflammatory response characteristic of invasive meningococcal disease.

\section{IMMUNE RECOGNITION OF INVASIVE DISEASE Complement}

The complement system of plasma proteins is strongly activated in response to meningococcal infection. ${ }^{12} 2728$

There are three principal pathways by which complement may be activated: the classical pathway, which is antibody mediated; the alternative pathway, which is initiated by direct binding of complement components to the pathogen surface; and the more recently described mannose (or mannan) binding lectin (MBL) pathway. MBL, as the name suggests, is able to recognise and bind to mannose on pathogen surfaces. ${ }^{29}{ }^{30}$

The importance of these pathways in the defence against meningococci is illustrated by the fact that individuals who are deficient in complement proteins have a greatly increased risk of meningococcal disease. This will be discussed in more detail in a later section.

\section{Recognition of meningococci by the innate immune response}

Recent research has shed new light on the innate immune response to meningococci, particularly with respect to lipopolysaccharide (LPS), an important component of the Gram negative cell wall.

The concept of pattern recognition receptors is central to an understanding of the innate immune response. These are non-clonal receptors that can recognise structures common to many pathogenic organisms, known as pathogen associated molecular patterns. ${ }^{31}$ Thus, they can distinguish self from non-self, albeit with less specificity than adaptive immunity. The MBL pathway described above is an example of this nonspecific recognition, as are LPS binding protein, bactericidal permeability inducing protein (BPI), soluble CDI4, and acute phase reactants, such as $\mathrm{C}$ reactive protein and serum amyloid $\mathrm{P}$, all of which have been implicated in the recognition of meningococci..$^{27}{ }^{32-38}$ There has been much recent interest in the role of toll-like receptors (TLRs) in innate immunity ${ }^{39-42}$; TLR4 and TLR2 have both been investigated in the context of neisserial disease. ${ }^{43-45}$ TLR4 is of particular interest because it is believed to be the principal receptor for Gram negative organisms. ${ }^{46}$

\section{The role of adaptive immunity}

Antibody plays an important role in the defence against meningococcal disease, as a powerful activator of complement. ${ }^{28} 4788$

The importance of antibody is illustrated by the distinctive age distribution of meningococcal infection. The first, and larger, peak of incidence occurs in early childhood, between the ages of 6 months and approximately 2 years, with a second, slightly smaller, peak occurring in the late teenage years. The first peak coincides with the loss of maternal antibody from the infant circulation, whereas the second peak occurs when adolescents leave their communities to enter university halls of residence or military barracks, thus encountering new strains to which they may not have acquired immunity. ${ }^{17}{ }^{49}$ Adaptive immunity may be induced spontaneously by Neisseria meningitidis encountered in the community, or by cross immunity with non-pathogenic organisms such as Neisseria lactamica.

In view of the considerable morbidity and mortality of invasive disease, there is much interest in supplementing naturally acquired immunity by immunisation. Vaccines are now available for some, but not all, meningococcal serogroups. Polysaccharide vaccines for serogroups A/C/W135/Y have been available for many years, but unfortunately are not immunogenic in young children. In the UK, a conjugate meningococcal $C$ vaccine is now given to all children, and this offers good protection in the very young. ${ }^{50}$ Vaccines for serogroup B disease are technically more challenging: the group B capsular polysaccharide is poorly immunogenic because of its similarity to host antigens, such as the neural cell adhesion molecule. ${ }^{51}$ Research is currently under way to develop serogroup B vaccines that can overcome this problem. For a more detailed discussion of meningococcal vaccines, see Jódar et $a l^{52}$ MacLennan, ${ }^{53}$ and Peter. ${ }^{54}$

\section{From recognition to effector pathways}

The complement system has both recognition and effector functions. Once the cascade is activated, downstream effects include opsonisation and phagocytosis, ${ }^{55}$ lysis of meningococci by the membrane attack complex C5-9, and further activation of the inflammatory response via complement fragments. ${ }^{30}$

Pattern recognition receptors may be subdivided into two main classes: those mediating phagocytosis and those leading to the activation of proinflammatory pathways. ${ }^{56}{ }^{57}$ For example, CD14 is now known to associate with TLR4 on the cell membrane, initiating the cytokine response via the nuclear factor $\kappa \mathrm{B}$ pathway. ${ }^{58}$

\section{Cytokines}

Cytokine activation is an important event in the pathogenesis of meningococcal disease, ${ }^{59}$ and has considerable bearing on the clinical course. A fine balance must be achieved, because underactivation will result in an inadequate immune response, whereas overactivation can be extremely destructive.

During the acute phase of meningococcal infection, greatly raised plasma concentrations of tumour necrosis factor $\alpha$ (TNF- $\alpha$ ), IL-1, IL-6, and IL-10 can be demonstrated. ${ }^{60-62}$ Furthermore, cytokine values can be related to clinical severity: high concentrations of TNF- $\alpha$ and IL-6 in severe sepsis are associated with an increased risk of mortality, as are high concentrations of IL-10. ${ }^{60616364}$ Current research is directed at elucidating genetic determinants associated with this variation in the cytokine response; this will be discussed in a later section.

\section{"Cytokine activation is an important event in the pathogenesis of meningococcal disease, and has considerable bearing on the clinical course"}

The distinction between cause and effect-and hence benefit and harm-may be crucial when assessing candidate agents for immunomodulatory treatment. However, the relative roles of proinflammatory and anti-inflammatory cytokines are not clearly defined. ${ }^{64}$ In addition, mechanisms of cytokine control may vary with the disease course and with the clinical presentation: van Deuren et al report differences in the modulation of IL-1 $\beta$ in plasma and cerebrospinal fluid (CSF) in meningococcal disease (implying differences between septicaemia and meningitis), and between early and late stages of infection. ${ }^{65}$

\section{CLINICAL CONSEQUENCES OF IMMUNE ACTIVATION}

The well known clinical picture of purpuric skin rash and shock emerges when the activation of inflammatory mediators causes endothelial damage and capillary leakage. ${ }^{667}$ The high likelihood of disseminated intravascular coagulation in meningococcal disease ${ }^{68}$ is reflected in the close relation between the inflammatory and coagulation pathways. ${ }^{69-72}$ The combination of poor tissue perfusion and coagulopathy in turn causes the multiple organ failure and necrosis of extremities seen in the most severe cases, which may result in death or permanent disability. ${ }^{6}{ }^{73}$ 
Table 1 Characteristic features of meningococcal disease in patients with complement deficiency

\begin{tabular}{ll}
\hline Feature & Comment \\
\hline Unusual serogroup & $\begin{array}{l}\text { Infection with an unusual serogroup organism such as W135 is } \\
\text { strongly suggestive of complement deficiency }\end{array}$ \\
This seems to be particularly associated with terminal \\
Recurrent disease & $\begin{array}{l}\text { Complement component deficiency } \\
\text { Complement deficiency inheritance is usually autosomal } \\
\text { recessive or X linked (see text) }\end{array}$
\end{tabular}

A finding of any of these features should prompt testing of complement function.

\section{IMMUNOLOGICAL RISK FACTORS FOR MENINGOCOCCAL DISEASE}

Given the profound influence of immune activation and inflammatory mediators on the clinical course of meningococcal infection, it is tempting to speculate whether individuals at higher risk can be identified, and hence protected from the deleterious consequences of invasive disease.

This is not generally practical at a clinical level. However, several factors have been identified that have the potential to alter either the risk or the prognosis of infection.

\section{Age}

As previously mentioned, age is a risk factor in the incidence of meningococcal disease, and is related to antibody function. This informed the strategy for the introduction of meningococcal $\mathrm{C}$ vaccine in the UK, which initially targeted individuals under the age of $18 .^{53}$

Age may also determine the outcome of invasive infection, with a poorer prognosis seen in those at either extreme of age. $^{4}$

\section{Mucosal immunity}

Several sources have reported an increased incidence of meningococcal disease among smokers and those exposed passively to cigarette smoke ${ }^{17} 74-76$ or smoke from cooking fires. ${ }^{77}$ The effect persists after correcting for obvious socioeconomic confounders. Others note a higher incidence of confirmed viral upper respiratory tract infection in the days preceding the onset of meningococcal disease. ${ }^{49}$ 78-80 The mechanisms remain unclear, ${ }^{81}$ but these findings suggest that compromise of the mucosal barrier is an important risk factor for invasive disease.

\section{Generalised immune deficiency}

Interestingly, it appears that susceptibility to meningococcal infection is not necessarily increased in immune deficiency states.

In view of the importance of the antibody response, it is not surprising that there are reports of meningococcal infection in patients with hypogammaglobulinaemia. ${ }^{82}$ In contrast, the risk of meningococcal disease is relatively small in human immunodeficiency virus positive patients. ${ }^{83}$

Many authors recommend meningococcal immunisation for asplenic individuals. ${ }^{84-86}$ However, it is interesting to note that reviews of the literature and of series of asplenic patients do not suggest a high risk of meningococcal disease in these patients. ${ }^{86} 87$

\section{Complement deficiency}

It has long been known that deficiency of proteins in the classical, alternative, or terminal complement pathways predispose to invasive meningococcal disease (MBL will be discussed separately). The relative risk has been estimated at several thousands ${ }^{88}$; however, deficiency of complement proteins is extremely rare in the general population. A large study of military recruits found a prevalence of only $0.03 \% .{ }^{89}$
Assessing prevalence of complement deficiency in meningococcal disease

Because population based studies of such a rare condition are unlikely to be fruitful, several studies have looked for complement deficiency in patients known to have had meningococcal disease. Most have found complement deficiency in approximately $1-3 \%$ of their patients..$^{90}$ Recently, a study from Newcastle (UK) tested almost 300 children with meningococcal disease and identified complement deficiency (of C2) in only one child. ${ }^{92}$

In contrast, studies in Israel and Japan have found a much higher prevalence of complement deficiency, ${ }^{29}{ }^{93}$ indicating a strong geographical variation.

If the results from the Newcastle study are representative of the UK as a whole, they imply that complement deficiency accounts for only a very small proportion of meningococcal cases in this country.

Characteristics of meningococcal disease in patients with complement deficiency

Certain factors in the patient history or course of meningococcal disease may help identify individuals with complement deficiency. These factors are summarised in table $1 .{ }^{48}$

It is also noteworthy that the age distribution of meningococcal disease is altered in patients with complement deficiency, with a higher average age at presentation than the normal population. ${ }^{88} 9091$ In addition, some patients with complement deficiency experience a milder disease course ${ }^{48}$ However, the cause and magnitude of these effects are difficult to establish because these studies of necessity have small numbers of subjects.

\section{Inheritance}

Complement deficiencies show an autosomal recessive inheritance pattern, with the exception of properdin deficiency, which is X linked. ${ }^{48} 9394$

\section{Conclusion}

Although complement is important in the defence against neisserial infection, complement deficiency accounts for a very small proportion of meningococcal disease overall. Therefore, screening all survivors of meningococcal disease is unlikely to uncover many new cases, but the presence of risk factors such as unusual serogroup, recurrent disease, or a strong family history of meningococcal disease should alert clinicians to this possibility.

\section{THE SEARCH FOR A SUSCEPTIBILITY GENOTYPE}

It is reasonable to attribute at least some of the wide variation in the outcome of meningococcal disease to heritable factors. However, apart from the special case of complement, variation in immune response to meningococcal disease is unlikely to be at the simple level of sufficiency versus deficiency. It seems probable that the individual pattern of the immune response is determined by several factors, which may interact in complex ways. 
Several polymorphisms have been identified in pattern recognition receptors relevant to meningococcal disease, but not all polymorphisms are clearly associated with risk of sepsis. ${ }^{45} 9596$

Among the more convincing results is the finding that genetic variants of MBL are significantly associated with meningococcal disease. ${ }^{97} 98$ This is of considerable interest, because these variants are much more common in the general population than deficiencies in other components of the complement pathway. In addition, several studies report that Fc $\gamma$ receptor allotypes influence susceptibility to bacterial sepsis. ${ }^{99-101}$

\section{"Although complement is important in the defence against neisserial infection, complement deficiency accounts for a very small proportion of meningococcal disease overall"}

As previously mentioned, there is a strong relation between the outcome of meningococcal disease and concentrations of cytokines in plasma or CSF. The logical next step is to ascertain whether individual variations in cytokine responses are genetically determined. One such study examined first degree relatives of patients who had had meningococcal disease, measuring their capacity to produce TNF- $\alpha$ and IL-10 after ex vivo stimulation. They found that mortality in the patients was associated with low TNF- $\alpha$ and high IL-10 production in their healthy relatives. ${ }^{102}$

In an attempt to delineate the specific mechanisms of genetic variation in the cytokine response, several studies have implicated polymorphisms of cytokines or their regulators as determinants of susceptibility or severity of Gram negative sepsis, including meningococcal disease, ${ }^{99}{ }^{103-108}$ However, it is surprisingly difficult to relate genotype to phenotype, and results of different studies may be contradictory. ${ }^{105} 109110$

Finally, given the importance of the coagulation cascade in the pathogenesis of meningococcal disease, it is interesting to note that genetically based variations in plasminogen activator inhibitor 1 concentration are significantly associated with outcome. ${ }^{111}$

\section{Conclusion}

As Nadel has pointed out in a recent editorial, ${ }^{112}$ there are many pitfalls in searching for genetic associations in sepsis, and unless the many confounders and methodological traps are accounted for, a degree of scepticism is required when evaluating these studies. Nevertheless, it is an area of great interest because of the enormous benefits that could ensue from the ability to tailor therapeutic intervention to the genetic profile of the patient. ${ }^{110}$

\section{FUTURE DIRECTIONS}

Immunomodulatory treatment for meningococcal disease is a good idea in theory, but developing therapeutic agents for clinical use is not as straightforward as it may seem. An attempt to block TNF- $\alpha$ bioavailability actually worsened outcomes in some patients with sepsis, ${ }^{113}$ and fresh frozen plasma given to a patient with complement deficiency during an episode of meningococcal disease exacerbated the release of endotoxin into the circulation. ${ }^{114}$ This is very much a field where "a little knowledge is a dangerous thing".

As well as the unforeseen (with current knowledge, unforeseeable) side effects of treatment, there are several methodological obstacles to overcome in clinical trials. Disease progression in meningococcal disease is often devastatingly swift: there is little time in which to obtain informed consent from distressed relatives, enroll the patient in the trial, randomise for treatment, and administer the study drug. ${ }^{115} \mathrm{In}$ addition, meningococcal disease is relatively rare and multicentre trials are essential, but standardised treatment is hard

\section{Take home messages}

- Meningococcal disease remains an important public health problem

- Although prevention is ideal, until that is achieved a fundamentally different approach is required

- The immune response has a profound effect on the course and outcome of disease, and although we now have a better understanding of this response, merely identifying the relevant pathways and then blocking them is too simplistic an approach

- Successful immunomodulatory treatment requires a more complete understanding of the immune response so that harmful processes can be suppressed without compromising beneficial ones

- Individual variations in the response to meningococcal infection may require management tailored to individual genetic factors

- It is hoped that research in the next few years will provide some answers to these questions

to achieve because it can be difficult to justify rigid treatment protocols in desperately ill patients. The simultaneous use of several new treatment methods may result in a good clinical outcome, but the individual effects are then hard to disentangle. ${ }^{116-19}$ These difficulties are illustrated by a recent study of recombinant BPI in meningococcal sepsis, which showed a trend towards improved outcome, but did not achieve significance. ${ }^{115} 120$

Nonetheless, immunomodulatory treatment is a promising direction for research, and a large and well designed trial has reported improved mortality in patients with severe sepsis treated with recombinant activated protein C. ${ }^{69}{ }^{121}$ Interested readers are referred to specialised reviews for further discussion of treatment strategies for sepsis. ${ }^{110} 122123$

\section{CONCLUDING REMARKS}

Despite advances in prevention and in intensive care management, meningococcal disease remains an important public health problem. Prevention is the ideal, but this will not be possible for some time yet, and meanwhile, we need to explore new strategies for treating these seriously ill patients. Much progress has been made in elucidating the immunological basis for the high morbidity and mortality of this disease. However, it is clear that merely identifying the relevant pathways and then blocking them is too simplistic an approach for such a complex process. Successful immunomodulatory treatment requires a sophisticated understanding of the immune response, allowing us to suppress harmful processes without compromising beneficial ones. In addition, individual variation in the response to meningococcal infection may require management tailored to individual genetic factors. These are important questions for current and future research, and it will be very interesting indeed to see what progress is made in the next few years.

\section{Authors' affiliation}

A J Kvalsvig, D J Unsworth, Southmead Hospital, Bristol BS10 5NB, UK

\section{REFERENCES}

1 Cartwright K, Reilly S, White D, et al. Early treatment with parenteral penicillin in meningococcal disease. BM 1992;305:143-7.

2 Thorburn K, Baines P, Thomson A, et al. Mortality in severe meningococcal disease. Arch Dis Child 2001:85:382-5.

3 Booy R, Habibi P, Nadel S, et al. Reduction in case fatality rate from meningococcal disease associated with improved healthcare delivery. Arch Dis Child 2001;85:386-90.

4 Scholten RJPM, Biilmer HA, Valkenburg HA, et al. Patient and strain characteristics in relation to the outcome of meningococcal disease: a multivariate analysis. Epidemiol Infect 1994;1 12:115-24. 
5 Sørensen HT, Nielsen GL, Schønheyder HC, et al. Outcome of pre-hospital antibiotic treatment of meningococcal disease. J Clin Epidemiol 1998;51:717-21

6 Edwards MS, Baker CJ. Complications and sequelae of meningococcal infections in children. J Pediatr 1981;99:540-5.

7 Wylie PAL, Stevens D, Drake W, III, et al. Epidemiology and clinical management of meningococcal disease in west Gloucestershire: retrospective, population based study. BM 1997;315:774-9.

8 Strang JR, Pugh EJ. Meningococcal infections: reducing the case fatality rate by giving penicillin before admission to hospital. BM 1992:305:143.

9 Mercier J-C, Beaufils F, Hartmann J-F, et al. Hemodynamic patterns of meningococcal shock in children. Crit Care Med 1988;16:27-33

10 Cartwright K, Ala'Aldeen DAA. Neisseria meningitidis: clinical aspects. $J$ Infect 1997;34:15-19.

11 Leteurtre S, Leclerc F, Martinot A, et al. Can generic scores (pediatric risk of mortality and pediatric index of mortality) replace specific scores in predicting the outcome of presumed meningococcal septic shock in children? Crit Care Med 2001;29:1239-46.

12 Hazelzet JA, de Groot R, van Mierlo G, et al. Complement activation in relation to capillary leakage in children with septic shock and purpura. Infect Immun 1998;66:5350-6.

13 Bone RC. Sepsis, the sepsis syndrome, multi-organ failure: a plea for comparable definitions. Ann Intern Med 1991;1 14:332-3.

14 Bolt P, Britto J, Nadel S, et al. Meningococcal disease due to W135: fresh public health concerns. Arch Dis Child 2001;84:90-1.

15 PHLS. Meningitis. 1999/2000 review of communicable diseases in England and Wales. 2000:1-10.

16 Caugant DA, Høiby EA, Magnus P, et al. Asymptomatic carriage of Neisseria meningitidis in a randomly sampled population. J Clin Microbiol 1994;32:323-30

17 Neal KR, Nguyen-Van-Tam JS, Jeffrey $N$, et al. Changing carriage rate of Neisseria meningitidis among university students during the first week of term: a cross sectional study. BM 2000;320:846-9.

$18 \mathrm{Sim}$ RJ, Harrison MM, Moxon ER, et al. Underestimation of meningococci in tonsillar tissue by nasopharyngeal swabbing. Lancet 2000;356: 1653-4.

19 Virii M. Mechanisms of microbial adhesion; the paradigm of Neisseriae. In: McCrae MA, Saunders JR, Smyth CJ, et al, eds. Molecular aspects of host-pathogen interaction. Cambridge: Cambridge University Press, 1997:95-110.

20 Billker O, Popp A, Gray-Owen SD, et al. The structural basis of CEACAM-receptor targeting by neisserial Opa proteins. Trends Microbiol 2000;8:258-60; discussion:260-1.

21 de Vries FP, van der Ende A, van Putten JPM, et al. Invasion of primary nasopharyngeal epithelial cells by Neisseria meningitidis is controlled by phase variation of multiple surface antigens. Infect Immun 1996:64:2998-3006.

22 Bayliss CD, Field D, Moxon ER. The simple sequence contingency loci of Haemophilus influenzae and Neisseria meningitidis. J Clin Invest 2001;107:657-62

23 Read RC, Zimmerli S, Broaddus VC, et al. The $(\alpha 2>8)$-linked polysialic acid capsule of group B Neisseria meningitidis modifies multiple steps during interaction with human macrophages. Infect Immun 1996;64:3210-17

24 Lindahl G, Sjöbring U, Johnsson E. Human complement regulators: a major target for pathogenic microorganisms. Curr Opin Immunol 2000;1 2:44-51.

25 Rautemaa R Meri S. Complement-resistance mechanisms of bacteria. Microbes Infect 1999;1:785-94.

26 Lorenzen D, Düx F, Wölk U, et al. Immunoglobulin Al protease, an exoenzyme of pathogenic Neisseriae, is a potent inducer of proinflammatory cytokines. J Exp Med 1999;190:1049-58.

27 Jack DL, Dodds AW, Anwar N, et al. Activation of complement by mannose-binding lectin on isogenic mutants of Neisseria meningitidis serogroup B. J Immunol 1998;160:1346-53

28 Jarvis GA, Griffiss JM. Human IgA 1 initiates complement-mediated killing of Neisseria meningitidis. J Immunol 1989;143:1703-9.

29 Walport MJ. Complement: first of two parts. N Engl J Med 2001;344:1058-66.

30 Janeway CA, Jr, Travers P, Walport M, et al. Immunobiology: the immune system in health and disease. Edinburgh: Current Biology Publications/Garland/Churchill Livingstone, 1999.

31 Janeway CA, Jr. How the immune system works to protect the host from infection: a personal view. Proc Natl Acad Sci U S A 2001;98:7461-8.

32 Mathison JC, Tobias PS, Wolfson E, et al. Plasma lipopolysaccharide (LPS)-binding protein: a key component in macrophage recognition of gram-negative LPS. J Immunol 1992;149:200-6.

33 Noursadeghi M, Bickerstaff MCM, Gallimore JR, et al. Role of serum amyloid $\mathrm{P}$ component in bacterial infection: protection of the host or protection of the pathogen. Proc Natl Acad Sci U S A 2000;97:14584-9.

34 Jack DL, Klein N, Turner MW. Mannose-binding lectin: targeting the microbial world for complement attack and opsonophagocytosis. Immunol Rev 2001;180:99.

35 Le Roy D, Di Padova F, Adachi Y, et al. Critical role of lipopolysaccharide-binding protein and CDI 4 in immune responses against gram-negative bacteria. J Immunol 2001;167:2759-65.

36 Ingalls RR, Heine $H$, Lien $E$, et al. Lipopolysaccharide recognition, CD14, and lipopolysaccharide receptors. Infect Dis Clin North Am $1999 ; 13: 341-53$

37 Elsbach P, Weiss J. Role of the bactericidal/permeability-increasing protein in host defence. Curr Opin Immunol 1998;10:45-9.
38 Neth O Jack DL, Dodds AW, et al. Mannose-binding lectin binds to a range of clinically relevant microorganisms and promotes complement deposition. Infect Immun 2000;68:688-93.

39 Muzio M, Polentarutti N, Bosisio D, et al. Toll-like receptors: a growing family of immune receptors that are differentially expressed and regulated by different leukocytes. J Leukoc Biol 2000;67:450-6.

40 Beutler B. Tlr4: central component of the sole mammalian LPS sensor. Curr Opin Immunol 2000; 12:20-6

41 Medzhitov R, Preston-Hurlburt P, Janeway CA, Jr. A human homologue of the drosophila Toll protein signals activation of adaptive immunity. Nature 1997;388:394-7.

42 Aderem A, Ulevitch RJ. Toll-like receptors in the induction of the innate immune response. Nature 2000;406:782-7.

43 Pridmore AC, Wyllie DH, Abdillahi $F$, et al. A lipopolysaccharide-deficient mutant of Neisseria meningitidis elicits attenuated cytokine release by human macrophages and signals via Toll-like receptor (TLR) 2 but not via TLR4/MD2. J Infect Dis 2001;183:89-96.

44 Massari P, Henneke P, Ho Y, et al. Immune stimulation by neisserial porins is toll-like receptor 2 and MyD88 dependent. J Immunol 2002; 168: 1533-7.

45 Read RC, Pullin J, Gregory S, et al. A functional polymorphism of Toll-like receptor 4 is not associated with likelihood or severity of meningococcal disease. J Infect Dis 2001;184:640-2.

46 Chow JC, Young DW, Golenbock DT, et al. Toll-like receptor-4 mediates lipopolysaccharide-induced signal transduction. J Biol Chem 1999;274: 10689-92.

47 Vidarsson G, van der Pol WL, van den Elsen JMH, et al. Activity of human $\lg G$ and $\lg A$ subclasses in immune defense against Neisseria meningitidis serogroup B. J Immunol 2001;166:6250-6.

48 Ross SC, Densen P. Complement deficiency states and infection: epidemiology, pathogenesis and consequences of neisserial and other infections in an immune deficiency. Medicine 1984;63:243-73.

49 Bruce MG, Rosenstein NE, Capparella JM, et al. Risk factors for meningococcal disease in college students. JAMA 2001;286:688-93.

50 Richmond P, Borrow R, Goldblatt D, et al. Ability of 3 different meningococcal $C$ conjugate vaccines to induce immunologic memory after a single dose in UK toddlers. J Infect Dis 2001;183:160-3.

51 Finne J, Bitter-Suermann D, Goridis C, et al. An lgG monoclonal antibody to group $B$ meningococci cross-reacts with developmentally regulated polysialic acid units of glycoproteins in neural and extraneural tissues. J Immunol 1987;138:4402-7.

52 Jódar L, Feavers IM, Salisbury D, et al. Development of vaccines against meningococcal disease. Lancet 2002;359:1499-5081

53 MacLennan J. Meningococcal group C conjugate vaccines. Arch Dis Child 2001;84:383-6.

54 Peter G. Update on meningococcal vaccine. Pediatr Infect Dis 2001;20:311-12.

55 Ross SC, Rosenthal PJ, Berberich HM, et al. Killing of Neisseria meningitidis by human neutrophils: implications for normal and complement-deficient individuals. J Infect Dis 1987;155:1266-75.

56 Jack DL, Jarvis GA, Booth $\mathrm{CL}$, et al. Mannose-binding lectin accelerates complement activation and increases serum killing of Neisseria meningitidis serogroup C. J Infect Dis 2001;184:836-45.

57 Jack DL, Read RC, Tenner AJ, et al. Mannose-binding lectin regulates the inflammatory response of human professional phagocytes to Neisseria meningitidis serogroup B. J Infect Dis 2001;184:1152-62.

58 Jiang Q, Akashi S, Miyake K, et al. Cutting edge: lipopolysaccharide induces physical proximity between CDI4 and Toll-like receptor (TLR4) prior to nuclear translocation of NF-kB. J Immunol 2000;165:3541-4.

59 Casey LC. Immunologic response to infection and its role in septic shock. Crit Care Clin 2000;16:193-213.

60 Waage A, Brandtzaeg P, Halstensen A, et al. The complex pattern of cytokines in serum from patients with meningococcal septic shock. J Exp Med 1989.169:333-8.

61 Riordan FAI, Marzouk O, Thompson APJ, et al. Proinflammatory and anti-inflammatory cytokines in meningococcal disease. Arch Dis Child 1996;75:453-4

62 van Deuren $M$, Brandtzaeg $P$, van der Meer J. Update on meningococcal disease with emphasis on pathogenesis and clinical management. Clin Microbiol Rev 2000;13:144-66.

63 Casey LC, Balk RA, Bone RC. Plasma cytokine and endotoxin levels correlate with survival in patients with the sepsis syndrome. Ann Intern Med 1993;1 19:771-8.

64 Lehmann AK, Gorringe AR, Reddin KM, et al. Human opsonins induced during meningococcal disease recognise transferrin binding protein complexes. Infect Immun 1999;67:6526-32.

65 van Deuren M, van der Ven-Jongekriig J, Vannier E, et al. The pattern of interleukin-1 $\beta$ (IL-1 $\beta$ ) and its modulating agents IL-1 receptor antagonist and IL-1 soluble receptor type II in acute meningococcal infections. Blood 1997;90:1101-8.

66 Parrillo JP. Pathogenetic mechanisms of septic shock. N Engl J Med 1993;328: 1471-8.

67 Hack CE, Zeerleder S. The endothelium in sepsis: source of and a target for inflammation. Crit Care Med 2001;29:S21-7.

68 Mirlashari MR, Høiby EA, Holst J, et al. Outer membrane vesicles from Neisseria meningitidis: effects on tissue factor and plasminogen activator inhibitor-2 production in human monocytes. Thromb Res 2001; 102:375-80

69 Bernard GP, Vincent J-L, Laterre P-F, et al. Efficacy and safety of recombinant human activated protein $C$ for severe sepsis. N Engl J Med 2001;344:699-709. 
70 Levi $\mathbf{M}$, ten Cate $\mathrm{H}$. Disseminated intravascular coagulation. N Engl J Med 1999:341:586-92.

71 Marshall JC. Inflammation, coagulopathy, and the pathogenesis of multiple organ dysfunction syndrome. Crit Care Med 2001;29:S99-106.

72 de Kleiin ED, Hazelzet JA, Kornelisse RF, et al. Pathophysiology of meningococcal sepsis in children. Eur J Pediatr 1998;157:869-80.

73 Briassoulis G, Narlioglou M, Zavras N, et al. Myocardial injury in meningococcus-induced purpura fulminans in children. Intensive Care Med 2001;27:1073-82.

74 Stanwell-Smith RE, Stuart JM, Hughes AO, et al. Smoking, the environment and meningococcal disease: a case-control study. Epidemiol Infect 1994; 112:315-28.

75 Kriz P, Bobak M, Kriz B. Parental smoking, socioeconomic factors, and risk of invasive meningococcal disease in children: a population based case-control study. Arch Dis Child 2002;83:117-21.

76 Fischer M, Hedberg K, Cardosi P. Tobacco smoke as a risk factor for meningococcal disease. Pediatr Infect Dis 1997;16:979-83.

77 Hodgson A, Smith T, Gagneux S, et al. Risk factors for meningococcal meningitis in northern Ghana. Trans R Soc Trop Med 2001;95:477-80.

78 Cartwright $\mathrm{K}$, Jones DM, Smith $\mathrm{A}$, et al. Influenza $\mathrm{A}$ and meningococcal disease. Lancet 1991;338:554-7.

79 Stephens DS, Hajieh RA, Baughman WS, et al. Aporadic meningocococcal disease in adults: results of a 5 -year population-based study. Ann Intern Med 1995;123:937-40.

80 Moore PS, Hierholzer J, DeWitt W, et al. Respiratory viruses and mycoplasma as cofactors for epidemic group A meningococcal meningitis. JAMA 1990;264:1271-5.

81 Young LS, LaForce FM, Head JJ, et al. A simultaneous outbreak of meningococcal and influenza infections. N Engl J Med 1972;287:5-9.

82 Salit IE. Meningococcaemia caused by serogroup W135. Association with hypogammaglobulinaemia. Arch Intern Med 1981;141:664-5.

83 Selik RM, Chu SY, Ward JW. Trends in infectious diseases and cancers among persons dying of HIV infection in the United States from 1987 to 1992. Ann Intern Med 1995;123:933-6.

84 Lane PA. The spleen in children. Curr Opin Pediatr 1995;7:36-41.

85 Davidson RN, Wall RA. Prevention and management of patients without a spleen. Clin Microbiol Infect 2001;7:657-60.

86 Spickett GP, Bullimore J, Wallis J, et al. Northern region asplenia register-analysis of first two years. J Clin Pathol 1999:52:424-9.

87 Loggie BW, Hinchey EJ. Does splenectomy predispose to meningococcal sepsis? An experimental study and clinical review. J Pediatr Surg 1986;21:326-30.

88 Figueroa J, Andreoni J, Densen P. Complement deficiency states and meningococcal disease. Immunol Res 1993;12:295-311.

89 Hassig A, Borel JF, Ammann P. Essentielle hypokomplementamie. Pathologie Microbiologie 1964;27:527-42.

90 Fijen CAP, Kuijper EJ, te Bulte MT, et al. Assessment of complement deficiency in patients with meningococcal disease in the Netherlands. Clin Infect Dis 1999;28:105.

91 Platonov AE, Beloborodov VB, Vershinina IV. Meningococcal disease in patients with late complement component deficiency: studies in the U.S.S.R. Medicine 1993;72:374-92

92 Hoare S, El-Shazalie O, Clark JE, et al. Investigation for complement deficiency following meningococcal disease. Arch Dis Child 2002:86:215-17.

93 Schlesinger $M$, Nave $Z$, Slater PE, et al. Prevalence of hereditary properdin, $C 7$ and $C 8$ deficiencies in patients with meningococcal infections. Clin Exp Immunol 1990;81:423-7.

94 Fijen CAP, van den Bogaard R, Schipper $M$, et al. Properdin deficiency: molecular basis and disease association. Mol Immunol 1999-36:863-7.

95 Hubacek JA, Stüber F, Fröhlich D, et al. The common functional $C(-159) T$ polymorphism within the promoter region of the lipopolysaccharide receptor CDI 4 is not associated with sepsis development or mortality. Genes Immun 2000;1:405-7.

96 Hubacek JA, Stüber F, Fröhlich D, et al. Gene variants of the bactericidal/permeability increasing protein and lipopolysaccharide binding protein in sepsis patients: gender-specific genetic predisposition to sepsis. Crit Care Med 2001;29:557-61.

97 Hibberd ML, Sumiya M, Summerfield JA, et al., Meningoccal Research Group. Association of variants of the gene for mannose-binding lectin with susceptibility to meningococcal disease. Lancet 1999;353:104953.
98 Summerfield JA, Sumiya M, Levin M, et al. Association of mutations in mannose binding protein gene with childhood infection in consecutive hospital series. BM 1997;314:1229-36.

99 van der Pol WL, Huizenga TWJ, Vidarsson G, et al. Relevance of Fcy receptor and interleukin-10 polymorphisms for meningococcal disease. J Infect Dis 2001;184:1548-55.

100 Domingo $P$, Muñis-Diaz E, Baraldès MA, et al. Associations between Fc gamma receptor IIA polymorphisms and the risk and prognosis of meningococcal disease. Am J Med 2002;112:19-25.

101 Teczan I, Berkel Al, Ersoy F, et al. Fcy receptor allotypes in children with bacterial meningitis - a preliminary study. Turk J Pediatr 1998:40:533-8.

102 Westendorp RGJ, Langermans JA, Huizenga TWJ, et al. Genetic influence on cytokine production and fatal meningococcal disease. Lancet 1997;349:170-3.

103 Nadel S, Newport M, Booy R, et al. Variation in the tumour necrosis factor- $\alpha$ gene promoter region may be associated with death from meningococcal disease. J Infect Dis 1996;174:878-80.

104 Appoloni O, Dupont E, Vandercruys $M$, et al. Association of tumor necrosis factor-2 allele with plasma tumor necrosis factor- $\alpha$ levels and mortality from septic shock. Am J Med 2001;1 10:486-8.

105 Fijen JW, Tulleken JE, Hepkema BG, et al. The influence of tumor necrosis factor- $\alpha$ and interleukin-10 gene promoter polymorphism on the inflammatory response in experimental human endotoxemia. Clin Infect Dis 2001;33:1601-3.

106 Fang XM, Schröder S, Hoeft A, et al. Comparison of two polymorphisms of the interleukin-1 gene family: interleukin-1 receptor antagonist polymorphism contributes to susceptibility to severe sepsis. Crit Care Med 1999;27: 1330-4.

107 Read RC, Camp NJ, di Giovine FS, et al. An interleukin-1 genotype is associated with fatal outcome of meningococcal disease. J Infect Dis 2000;182:1557-60

108 van Deventer SJH. Cytokine and cytokine receptor polymorphisms in infectious disease. Intensive Care Med 2000;26:S98-102.

109 Booy R, Nadel S, Hibberd ML, et al. Genetic influence on cytokine production in meningococcal disease. Lancet 1997;349:1176.

110 Stüber $\mathbf{F}$. Effects of genomic polymorphisms on the course of sepsis: is there a concept for gene therapy? J Am Soc Nephrol 2001;12:S60-4

111 Hermans PW, Hibberd ML, Booy R, et al. 4G/5G promoter polymorphism in the plasminogen-activator-inhibitor-1 gene and outcome of meningococcal disease. Meningococcal research group. Lancet 1999;354:556-60.

112 Nadel S. Helping to understand studies examining genetic susceptibility to sepsis [editorial]. Clin Exp Immunol 2002;127:191-2.

113 Fisher CJ, Agosti JM, Opal SM, et al. Tumor necrosis factor receptor:Fc fusion protein for septic shock. N Engl J Med 1996;334:1697-702.

114 Lehner PJ, Davies KA, Walport M, et al. Meningococcal septicaemia in a C6-deficient patient and effects of plasma transfusion on lipolysaccharide release. Lancet 1992;340:1379-81.

115 Giroir BP, Scannon PJ, Levin M. Bactericidal/permeability-increasing protein-lessons learned from the phase III, randomized, clinical trial of $\mathrm{rBP}_{21}$ for adjunctive treatment of children with severe meningococcaemia. Crit Care Med 2001;29:S130-5.

116 Smith OP, White B, Vaughan D, et al. Use of protein-C concentrate, heparin, and haemodiafiltration in meningococcus-induced purpura fulminans. Lancet 1997;350:1590-3.

117 Duncan A. New therapies for severe meningococcal disease but better outcomes? Lancet 1997;350:1565-8.

118 Leclerc F, Cremer R, Leteurtre $S$, et al. Protein $C$ concentrate and recombinant tissue plasminogen activator in meningococcal septic shock. Crit Care Med 2000;28: 1694-5.

119 Gerson WT, Dickerman JD, Bovill EG, et al. Severe acquired protein C deficiency with disseminated intravascular coagulation: treatment with protein C concentrate. Pediatrics 1993;91:418-22.

120 Levin M Quint PA, Goldstein B, et al. Recombinant bactericidal/ permeability-increasing protein $\left(\mathrm{rBP}_{21}\right)$ as adjunctive treatment for children with severe meningococcal sepsis: a randomised trial. Lancet 2000;356:961-7

121 Matthay $\mathbf{M}$. Severe sepsis-a new treatment with both anticoagulant and antiinflammatory properties. N Engl J Med 2001;344:759-62.

122 Glauser MP. Pathophysiologic basis of sepsis: considerations for future strategies of interevention. Crit Care Med $2001 ; 28:$ S4-8.

123 Cohen J. Meningococcal disease as a model to evaluate novel anti-sepsis strategies. Crit Care Med 2000;28:S64-7. 